\section{СТАТИСТИКА, ЕСЕП ЖӘНЕ АУДИТ}

\section{СТАТИСТИКА, УЧЕТ И АУДИТ}

\section{STATISTICS, ACCOUNT AND AUDIT}

ISSN 1563-2415

Ежеквартальный научнопрактический журнал издается с 1999 года.

№ 1(84) 2022

Учредитель «Алматинский гуманитарно-экономический университет»

Алматинский гуманитарно-экономический университет

Главный редактор

Досаева С.К.

Заместители гл. редактора:

Корвяков В.А. - д.п.н., проф., ректор АГЭУ

Сейтхамзина Г.Ж. - к.э.н., проф., проректор по науке и инновациям АГЭУ

\section{Члены редколлегии:}

Амирханова Г.А. - доктор $\mathrm{PhD}$, снс ИИВТ КН МОН РК, г.Нур-Султан, Казахстан

Бекенова Л.М. - к.э.Н., профессор, проректор по академической работе АГЭУ

Дауренбеков А.К. - к.э.н., проф. АГЭУ, г. Алматы, Казахстан

Дырка Стефан - д.э.н., проф., Верхнесилезский экономический Университет имени Вой- цеха Корфанти в Катовицах, Польша

Ерж⿻анов М.С. - д.э.н., проф., партнер «Grant Thornton», г.Алматы, Казахстан

Ешпанова Д.Д. - к.э.н., доцент кафедры "Учет, аудит и статистика" АГЭУ, г.Алматы, Казахстан

Макыш С.Б. - д.э.н., проф., декан экономического факультета, ЕНУ им.Л.Н.Гумилева, г.Нур-Султан, Казахстан

Мезенцева T.M. - д.э.н., профессор департамента учета, анализа и аудита Финансового Университета при правительстве РФ, г.Москва, Россия

Назарова В.Л. - Д.э.н., проф., зав. кафедрой "Учет, аудит и статистика" АГЭУ, г.Алматы, Казахстан

Рахметова P.У. - д.э.н, проф., Туран - Астана, Нурсултан, Казахстан

Сейдахметова Ф.С. - д.э.н., проф. кафедры "Учет, аудит и статистика" АГЭУ, г.Алматы, Казахстан

Taunoв T.A. - к.э.н., проф., АГЭУ, г.Алматы, Казахстан

Тайгашинова К.T. - д.э.Н., проф кафедры "Учет, аудит и статистика", АГЭУ, г.Алматы, Казахстан

Шокаманов Ю.К. - Д.э.н., проф., г.Нур-Султан, Казахстан

\section{Издательский центр}

Алматинского гуманитарно-

экономического университета

050035, г.Алматы,

ул.Жандосова, 59,

тел: +7 7273095820 ,

$+77273095815$

факс: + 77273093000

e-mail: zhurnal.aesa.99@mail.ru

www.journal.ageu.kz, www.ageu.kz

Ответственный за выпуск журнала Айтжанова Н.M.

Подписано в печать: 26.01.2022г.

Формат 70x108 1/16.

Бумага офсетная.

Тираж 300 экз.

\section{ИП «Аруна»}

г.Алматы, Алмалинский район, ул. Нурмакова, 26/195 кв. 49 e-mail: mail: iparuna@yandex.ru 
ISSN 1563-2415

Учреждение «Алматинский гуманитарно-экономический университет», 050035, г. Алматы, ул. Жандосова, 59, тел.(727) 309-58-20, 309-58-15, вн. 138 e-mail: zhurnal.aesa.99@mail.ru, aesa2005@mail.ru

Website: journal.ageu.kz, www.ageu.kz

Регистрационное свидетельство № 9099-Ж от 25.03.2008 г. выдано Министерством культуры и информации Республики Казахстан, Комитетом информации и архивов

Журнал включен в Российский индекс научного цитирования (РИНЦ) и размещается в научной электронной библиотеке (WWW.ELIBRARY.RU) (Лицензионный договор с ООО «НЭБ» № 133-03/2016 г.Москва 11 марта 2016 г.). 
Раман Ибрахим, Сюзана Бахарудин

МЕЛИМАУ ПОЛИТЕХНИКАЛЫҚ ИНСТИТУТЫНДА КОВИД-19

ПАНДЕМИЯСЫ КЕЗІНДЕ СИНХРОНДАЛҒАН ОНЛАЙН ОҚЫТУҒА

КЕНЕТ ӨТУ: ИНЖЕНЕРЛІК ФАКУЛЬТЕТІ СТУДЕНТТЕРІ

ПЕРСПЕКТИВАСЫН САНДЫК ЗЕРТТЕУ ...

Нориымах Осман

4IR ЭЛЕМЕНТТЕРІН ҚОЛДАНУ АРҚЫЛЫ ТЖКБ ЦИФРЛАНДЫРУ.

Тан Си Мин

ЦИФРЛІК МІНЕЗ-ҚҰЛЫҚТЫ ДАМЫТУ ЖӘНЕ МУЛЬТИФИКАЦИЯ МЕН ИННОВАЦИЯЛЫҚ ОҚЫТУ ҚҰРАЛЫ РЕТІНДЕ ИНТЕГРАЦИЯЛАУ:

ОҚУДАҒЫ СТУДЕНТТЕРДІН МІНЕЗ-ҚҰЛҚЫНА ӘСЕРІ.

\section{Тео Пей Киан}

ӨНДІРІСТІК СТУДЕНТТЕРДІ ОҚУ ТИІМДІЛІГІНЕ ОҚУ

ИННОВАЦИЯЛАРЫНЫҢ ӘСЕРІ ЖОҒАРЫ ОҚУ ОҚУЫНДАҒЫ

ДИЗАЙН.....

Дви Вахюнинсси, Сламет Утомо, Шри Сурачми, Сажида Досаева

КОВИД-19 ПАНДЕМИЯСЫ КЕЗІНДЕ ОНЛАЙН ОҚЫТУДЫН САПАСЫН

АРТТЫРУДАҒЫ КӨШБАСШЫНЫН РӨЛІ.

А.Адельбаева, А. Бекметова

АЗЫҚ-ТҮЛІКПЕН МОЛЫҚТЫРУДЫ ҚАМТАМАСЫЗ ЕТУ ҮШІН

АГРАРЛЫҚ НАРЫҚТЫ РЕТТЕУ.

А. Джумабаева, Д. Бабаш, А.Кенджасарова, Р.Арзикулова

ҚАЗАҚСТАННЫН АЗЫҚ-ТҮЛІК ҚАУІПСІЗДІГІН ҚАМТАМАСЫЗ ЕТУ:

ТЕОРИЯ, ӘДІСТЕМЕ ЖӘНЕ ПРАКТИКА

А. Нуртаева, С. Айткулова, А.Садвакасова, А.Кұрмантаева

КОММЕРЦИЯЛЫҚ БАНКТЕРДЕГІ ТӘУЕКЕЛДЕРДІ БАСҚАРУ ЖҮЙ-

ЕСІНІН ТИІМДІЛІГІН ТАЛДАУ.

\section{А.Рамазанов, С.Базылхан}

ҚОНАҚЖАЙЛЫЛЫҚТЫН КОНЦЕПТУАЛДЫҚ НЕГІЗДЕРІ.

А.Рамазанов, Ж.Куралов

ҚОНАҚ ҮЙ ІСІНІҢ ЭКОНОМИКАЛЫҚ СИПАТТАМАСЫ.

II.A. Topzaeвa

КОМПАНИЯ ҚЫЗМЕТІНДЕГІ ИНТЕРНЕТ МАРКЕТИНГ 


\section{СОДЕРЖАНИЕ}

Раман Ибрагим, Сюзана Бахарудин

ВНЕЗАПНЫЙ ПЕРЕХОД К СИНХРОНИЗИРОВАННОМУ ОНЛАЙНОБУЧЕНИЮ ВО ВРЕМЯ ПАНДЕМИИ COVID-19 В ПОЛИТЕХНИЧЕСКОМ ИНСТИТУТЕ МЕРЛИМАУ: КОЛИЧЕСТВЕННОЕ ИССЛЕДОВАНИЕ ПЕРСПЕКТИВ СТУДЕНТОВ ФАКУЛЬТЕТА МАШИНОСТРОЕНИЯ.............. 6

Норшыммах Осман

ОЦИФРОВКА ТVЕТ С ИСПОЛЬЗОВАНИЕМ ЭЛЕМЕНТОВ 4IR.

Тан Си Мин

РАЗРАБОТКА ЦИФРОВОГО ПОВЕДЕНИЯ И ИНТЕГРИРОВАНИЕ С МУЛЬТИФИКАЦИЕЙ В КАЧЕСТВЕ ИННОВАЦИОННОГО УЧЕБНОГО СРЕДСТВА: ВЛИЯНИЕ НА ПОВЕДЕНИЕ УЧАЩИХСЯ В ОБУЧЕНИИ.......

\section{Тео Пей Киан}

ВЛИЯНИЕ ОБУЧАЮЩИХ ИННОВАЦИЙ НА ЭФФЕКТИВНОСТЬ ОБУЧЕНИЯ СТУ ДЕНТОВ ПРОМЫШЛЕННЫХ ДИЗАЙН В ВЫСШЕМ ОБРАЗО-

ВАНИИ.

Dwi Wahyuningsih, Slamet Utomo, Sri Surachmi, Сажида Досаева

РОЛЬ РУКОВОДИТЕЛЯ В ПОВЫШЕНИИ КАЧЕСТВА ОНЛАЙН-

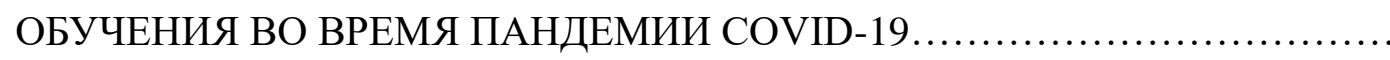

А.Адельбаева, А.Бекметова

РЕГУЛИРОВАНИЕ АГРАРНОГО РЫНКА ДЛЯ ОБЕСПЕЧЕНИЯ ПРОДО-

ВОЛЬСТВЕННОГО НАСЫЩЕНИЯ.

А. Джумабаева, Д. Бабаш, А.Кенджасарова, Р. Арзикулова ОБЕСПЕЧЕНИЕ ПРОДОВОЛЬСТВЕННОЙ БЕЗОПАСНОСТИ КАЗАХСТАНА: ТЕОРИЯ, МЕТОДОЛОГИЯ И ПРАКТИКА.

А. Нуртаева, С. Айткулова, А.Садвакасова А. Құрмантаева

АНАЛИЗ ЭФФЕКТИВНОСТИ СИСТЕМЫ УПРАВЛЕНИЯ РИСКАМИ В КОММЕРЧЕСКИХ БАНКАХ

\section{Рамазанов А., С.Базылхан}

КОНЦЕПТУАЛЬНЫЕ ОСНОВЫ ГОСТЕПРИИМСТВА.

Рамазанов А., Ж.Куралов

ЭКОНОМИЧЕСКИЕ ХАРАКТИРИСТИКИ ГОСТИНИЧНОГО ДЕЛА.

U.A Торгаева

ИНТЕРНЕТ - МАРКЕТИНГ В КОМПАНИЯХ 


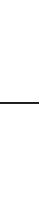

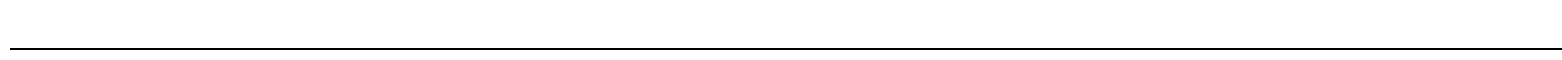

\section{Raman Ibrahim, Suzana Baharudin}

THE SUDDEN TRANSITION TO SYNCHRONIZED ONLINE LEARNING DURING THE COVID-19 PANDEMIC IN POLITEKNIK MERLIMAU: A QUANTITATIVE STUDY EXPLORING MECHANICAL ENGINEERING STUDENT'S PERSPECTIVES.

Norshymah Osman

DIGITALIZING TVET USING 4IR ELEMENTS.

Tan Si Min

DEVELOP DIGITAL STORYTELLING INTEGRATES WITH ANIMATION AS AN INNOVATIVE INSTRUCTIONAL TOOL: EFFECTS ON STUDENT'S BEHAVIOURAL ENGAGEMENT IN LEARNING.

Teo Pei Kian

THE EFFECT OF TEACHING INNOVATION ON LEARNING EFFECTIVENESS AMONG THE STUDENTS OF INDUSTRIAL

DESIGN IN HIGHER EDUCATION

Dwi Wahyuningsih, Slamet Utomo, Sri Surachmi, Sazhida Dossayeva

THE ROLE OF THE PRINCIPAL IN IMPROVING THE QUALITY OF ONLINE LEARNING DURING THE COVID-19 PANDEMIC

A. Adelbaeva Phd student, A. Bekmetova

REGULATION OF THE AGRICULTURAL MARKET TO ENSURE FOOD SATURATION

A. Dzhumabayeva, D. Babash, A. Kendzhasarova, R.Arzikulova

ENSURING FOOD SECURITY IN KAZAKHSTAN: THEORY, METHODOLOGY AND PRACTICE.

A. Nurtayeva, S. Aitkulova, A.Sadvakassova, A. Kurmantaeva

ANALYSIS OF THE EFFECTIVENESS OF THE RISK MANAGEMENT SYSTEM IN COMMERCIAL BANKS

Ramazanov A., C. Bazylhan

CONCEPTUAL BASIS OF HOSPITALITY.

Ramazanov A., Zh. Kuralov

ECONOMIC CHARACTERISTICS OF THE HOTEL BUSINESS

Torgaeva Sh.A

INTERNET MARKETING IN COMPANIES. 
Статистика, учет и аудит, $\mathbf{4 ( 8 4 ) 2 0 2 2}$ стр. 39 - 47

ГРНТИ 06.51.02

УДК 338

https://doi.org/10.51579/1563-2415.2022-1.01

\title{
THE EFFECT OF TEACHING INNOVATION ON LEARNING EFFECTIVE- NESS AMONG THE STUDENTS OF INDUSTRIAL DESIGN IN HIGHER EDUCATION
}

\author{
Teo Pei Kian \\ Southern University College, Malaysia \\ e-mail:pkteo@sc.edu.my
}

\begin{abstract}
This article discusses the effect of teaching innovation in Industrial Design education, it is needed to reinvent about everything to override challenge of public consciousness. Teaching innovation is including scientific advances, technology breakthroughs, new political, economic structures, environmental solutions, or an updated code of ethics for nowadays life. Everything demands innovative, out of box thinking is a must in teaching and learning. The challenge today for Industrial Design education is how to capture the students' attention, and putting across ideas in such a way that it stays with them long after they have left the classroom. This means that Industrial Design lecturers need a set of teaching innovation which influence innovative development. In this manner, the content explores to assimilate the elements, ideas and methods that consider as teaching innovation on learning effectiveness. The objectives of this article are to identify the effect of teaching innovation methods for an Industrial Design programme and to explore how processes of teaching innovation on learning effectiveness in Industrial Design programme. This article compiles secondary data on a topic by accredited scholars and researchers; critically reviews existing research on the topic; and analyses contrasting perspectives and theoretical approaches. In summary, this paper consolidates the concept of teaching innovation in Industrial Design education and the learning effectiveness among the Industrial Design students in higher education setting.
\end{abstract}

Keywords: Industrial Design Education, Teaching Innovation, Higher Education, Learning Effectiveness

Main provisions of the article. The topics discussed above focus mainly on the literature definition and an overview of Industrial Design teaching innovation, including strategies and ideas. It is important to have a full understanding of each topic and the relation between them. The objectives of research were achieved based on these findings. It is hoped that this research can help Industrial Design lecturers conduct the Industrial Design courses and improve the student learning effectiveness in higher education.

Introduction. Nowadays, the online and open education world is changing how education is delivered. Digital technologies are developing educational activities as well [1]; [2]. Within different level of education, innovative technologies have enormous potential to effect change of teaching method [3]. The education landscape is undergoing significant change as a result of teaching innovations. Lecturers and students are witnessing changes in the way higher education is taught and in the way students learn. Recent technologies and approaches 
to education are already having a clear and positive impact on higher education in $21^{\text {st }}$ century [4].

Many lecturers found out that inflexible timetables to be too rigid, have solved this via eliminating conventional classes altogether. With the assist of technology, design classes must not adhere to the constant layout approach characteristic of the conventional device. ID students stand to benefit lots from extra personalized design training and more mange over their own mastering skill, including hands on skill and software skill. The ramifications for lecturers are energizing, they become allowed to take on various jobs, including tutor, mentor and creator of activities that this present reality significance of subject material [5]. In reality, innovation and the present-day classroom version most customarily perform as antagonist. The device is evolving but not enough to get interest from young people equipped for the new global.

Background of Research. In $21^{\text {st }}$ century life, Industrial Design (ID) education need to reinvent about everything to override challenge of public consciousness. Teaching innovation on learning viability among ID students is including logical advances, innovation forward leaps, new political, financial designs, ecological arrangements, or a refreshed code of morals for these days' life. Everything demands innovative, out of box thinking is a must in teaching and learning [6].

Teaching innovation for ID programme need strategies to initiate learners and lecturer into effective ways to help learners engage in different activities based on ideas about teaching and learning process. Different learning strategies may be used in each of the active learning designs [7]. To meet $21^{\text {st }}$ century expectations in ID education, lecturers need to depart from the traditional ideas, pedagogies and need some changes to develop the sort of learning for ID students and their work futures. There are a number of ways that lecturers can use and provide students the tools and experiences with innovative mindset.

Objective. OECD [8] mentioned that design programmes are very common in many countries nowadays; creativity is increasingly important for lecturer teaching innovation for their professional success and that of their students, particularly given the learning effectiveness.

Teaching innovation should concentrate on encouraging development by setting interest, basic reasoning, profound comprehension, the guidelines and devices of request and imaginative conceptualizing at the focal point to the ID programme.

The objectives of this study are:

To study components of teaching innovation on learning effectiveness required in Industrial Design Programme.

To identify techniques and strategies for teaching innovation which provide Industrial Design students with a good outcome.

Meta-Analysis. Meta-analysis is a set of techniques used to combine statements from different journals, papers and articles into one report. In this article, meta-analysis combines information from multiple lecturers, scholars and researchers to increase the chances of finding valuable ideas.

In Table 1, eligibility, identifying studies, abstracting data are defined, and the results are discussed. The scope of analysis constitutes the study of teaching innovation for Industrial Design. This study acquired three sub-topics directly related to Industrial Design education. These three topics are: 1) A need for $21^{\text {st }}$ century Industrial Design Education, 2) Teaching Innovation for Active Learning Strategies, 3) Teaching Innovation for Active Learning Ideas. 
All of these topics play important roles in guiding lecturers to conduct teaching innovation on learning effectiveness in higher education for Industrial Design programme.

Table 1: Important Issues of Teaching Innovation for Industrial Design Programme

\begin{tabular}{|c|c|c|c|}
\hline $\begin{array}{l}\text { Accredited } \\
\text { Lecturers, } \\
\text { Scholars of } \\
\text { Researchers }\end{array}$ & $\begin{array}{l}\text { A Need } 21^{\text {st }} \text { Century In- } \\
\text { dustrial Design Educa- } \\
\text { tion }\end{array}$ & $\begin{array}{l}\text { Teaching Innovation for } \\
\text { Active Learning Strate- } \\
\text { gies }\end{array}$ & $\begin{array}{l}\text { Teaching Innovation } \\
\text { for Active Learning } \\
\text { Ideas }\end{array}$ \\
\hline Reeves [9] & $\begin{array}{l}\text { Lecturers need to exam- } \\
\text { ine their professional } \\
\text { practice and their impact } \\
\text { on student achievement } \\
\text { in } 21^{\text {st }} \text { century education }\end{array}$ & & \\
\hline $\begin{array}{l}\text { Carrol et al. } \\
{[10]}\end{array}$ & $\begin{array}{l}\text { Design thinking is a } \\
\text { power tool for learning } \\
\text { comes in the ways it can } \\
\text { support a diverse range } \\
\text { of interdisciplinary aca- } \\
\text { demic content }\end{array}$ & $\begin{array}{l}\text { Teaching lessons that } \\
\text { use design thinking as } \\
\text { leverage for learning can } \\
\text { provide rich experiences } \\
\text { that encourage the impo- } \\
\text { sition of a full set of } \\
\text { knowledge and skills }\end{array}$ & \\
\hline Nilson [11] & $\begin{array}{l}\text { Problem-based learning } \\
\text { offers students the op- } \\
\text { portunity to develop } \\
\text { skills }\end{array}$ & & \\
\hline Stuart [12] & $\begin{array}{l}\text { Problem-based learning } \\
\text { technique encourages } \\
\text { knowledge construction } \\
\text { among students }\end{array}$ & & \\
\hline $\begin{array}{l}\text { Berkeley } \\
{[13]}\end{array}$ & & $\begin{array}{l}\text { Multiple active learning } \\
\text { strategies may be used in } \\
\text { each of the active learn- } \\
\text { ing design. } \\
\text { Sit \& talk with peers } \\
\text { nearby, turn \& talk, in- } \\
\text { dividual or group } \\
\text { quizzed and jigsaws }\end{array}$ & \\
\hline $\begin{array}{l}\text { Dove \& } \\
\text { Revilla [14] }\end{array}$ & & & $\begin{array}{l}\text { From creating study } \\
\text { plans and keeping en- } \\
\text { gagement, to behavior } \\
\text { records and communi- } \\
\text { cating with students } \\
\text { out of the classroom, } \\
\text { mobile apps offer lec- } \\
\text { turers harness tech in } \\
\text { place of combating it }\end{array}$ \\
\hline
\end{tabular}




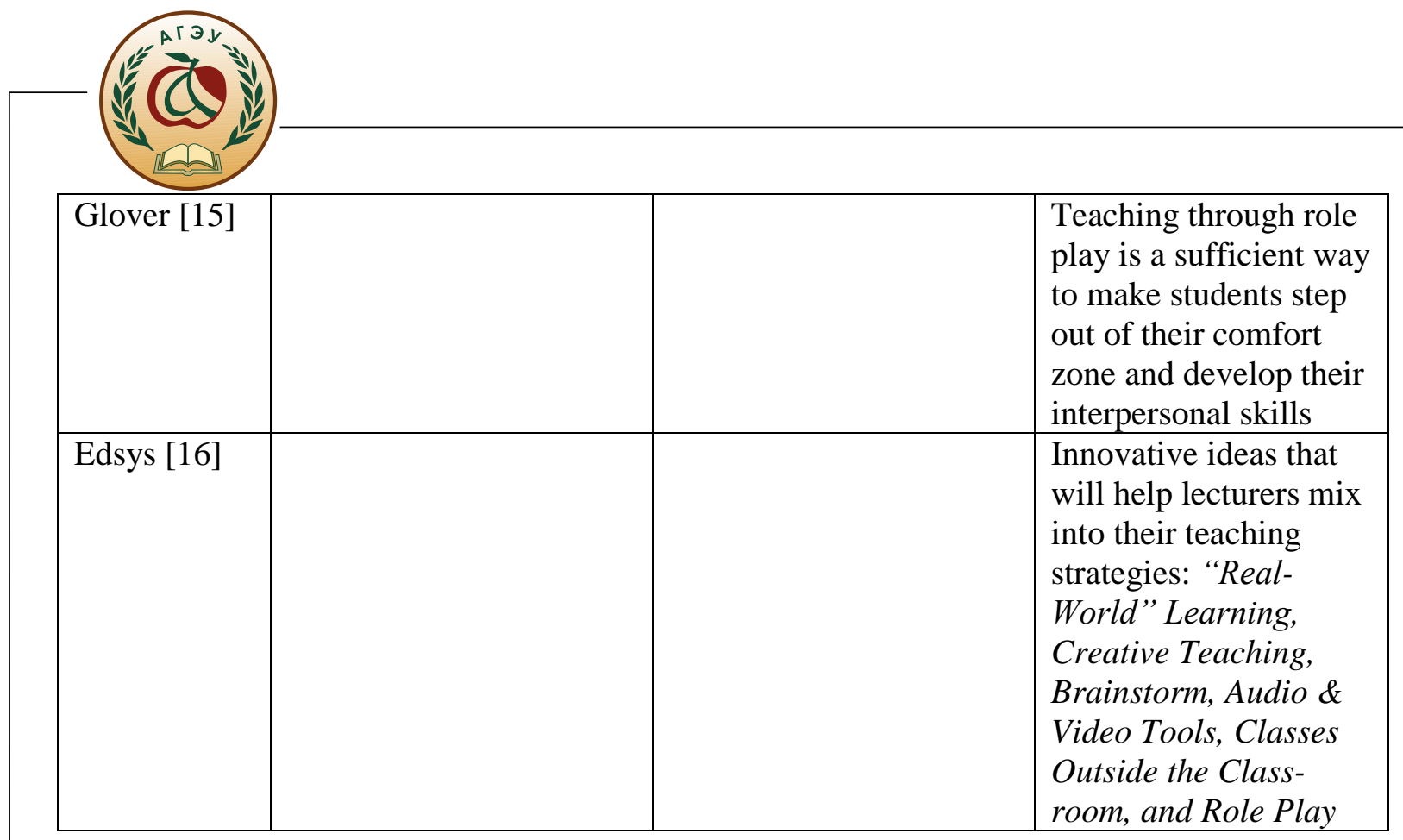

Results and Discussion. All the information is focused on teaching innovation on learning effectiveness for Industrial Design programme and divided into three topics where more will be explained about the teaching innovation of Industrial Design programmes. The topics clarify the understanding of $21^{\text {st }}$ century Industrial Design education need through teaching innovation strategies and ideas

A Need for $21^{\text {st }}$ Century Industrial Design Education. Reeves [9] expressed that lecturer need to look at their expert practice and their impact on student accomplishment. In the spirit of student-centered responsibility, a 21 st century education must consequently be attached to learning results and capability in both center subject information and 21 st century abilities that are normal and profoundly esteemed in and beyond school. There are various ways that teachers can utilize and furnish students the instruments and encounters with innovative mindset.

\section{Design Thinking to Optimize Student Learning}

Design thinking is a way to deal with discovering that centers around building up design inventive certainty through involved tasks that emphasis on empathy, advancing a predisposition toward activity, empowering ideation and encouraging dynamic critical thinking. It is a power tool for learning comes in the manners it can uphold a diverse range of interdisciplinary academic content [10]. Teaching lessons that use design thinking as influence for learning can give rich encounters that encourage the imposition of a full arrangement of knowledge and skills.

\section{Move from projects to Problem Based Learning}

Most lecturers have done projects, but the majority do not use the defined set of methods associated with high-quality problem-based learning (PBL). Nilson [11] pointed that a well-design PBL project offers students the opportunity to develop skills related to concept interpretation, critical thinking and analysis. Stuart [12] claimed that PBL technique encourages knowledge construction among students, stimulating students to integrate design process into activities in reality.

Teaching Innovation for Active Learning Strategies. Different strategies may be used in active learning of Industrial Design programme, especially for teaching innovation 


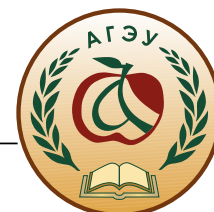

[17]. Multiple active learning strategies may be used in each of the active learning designs. Here is the list of strategies:

Sit \& talk with peers nearby

Disclose to design students that a think-pair-share permit them to initiate their earlier information and offer design thoughts regarding project. Design students get an opportunity to arrange their thoughts by utilizing this design. In this structure, students contemplate the project brief, the pair up with classmate to talk about their intuition, end up share their discussion with another group.

Turn and Talk

In a turn and talk, an inquiry concerning design problem is tossing to students and basically go to the individual close to them to examine. This can fill in as an agreeable route for students to impart their reasoning and thoughts to other people and set up for them to keep offering to the bigger group. lecturer doesn't have to hear every one of the substances shared, only the significant part of subject.

Individual or Group test

Give designs students a test that they complete exclusively and go in to be evaluated. Place students in a small group after the individual test and give a test once more. They will talk about the appropriate responses in their group and turn it in for a group score. Both tests are reviewed and if the group score is higher, the two evaluations are arrived at the midpoint of. The group score can't hurt somebody in the event that they have a higher individual score.

Jigsaws

Jigsaw conversation is a fun and dynamic group organization model that supports peer instructing and helpful learning. Design students work in small group to peruse project brief that has been coordinated into areas. Every student gets in the gathering to peruse one segment of the material furnished and afterward imparted the data to the remainder of their group. There are different changes of jigsaws, they read it separately and afterward talk about in their small group to ensure everybody in their group gets it [13].

Teaching Innovation for Active Learning Ideas. The challenge today for Industrial Design lecturer is the way to catch the students' attention and putting across thoughts so that it stays with them long after they have left the classroom. Edsys [16] listed some innovative ideas that will help lecturers mix into their showing strategies and make the class seriously fascinating.

\section{"Real-World" Learning}

Connect the lessons to real world learning. Share the real-world experiences with students to make teaching lessons fresh and interesting. Relating and demonstrating through real life situations, will make the theory easier to understand, students will get it very clear. For example, lecturers can make use of smart apps in class to make some sessions more fun and attractive. Dove \& Revilla [14] stated that from creating study plans and keeping engagement, to behavior records and communicating with students out of the classroom, mobile apps offer lecturers harness tech in place of combating it. For example, Kahoot (Figure 1) let lecturers turn the class lesson into a gameshow. Lecturers have to do is enter the prepared questions and answers into the site to create an instantly playable game with a web browser. Then the students just download to join in on the fun. 


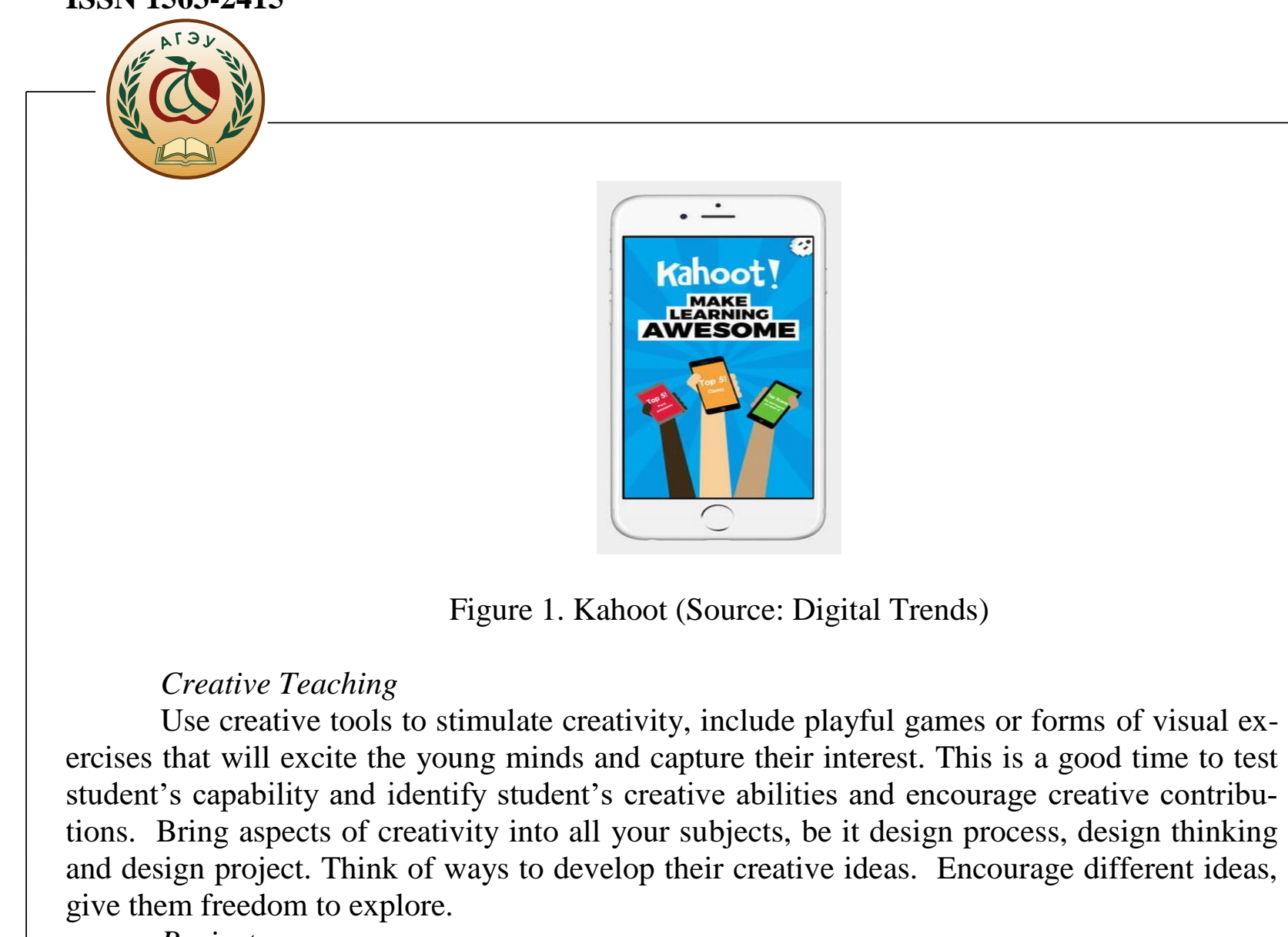

\section{Brainstorm}

Set aside a few minutes for brainstorming sessions to generate new ideas into classrooms. These sessions are an extraordinary method to get the expressive energies pumping. Design students will get various thoughts if numerous minds zeroing in on one single though and will likewise include everybody in class get into the conversation. This is an incredible stage for students to voice out their considerations. Lecturer can set a few guidelines before the brainstorming session start.

\section{Audio \& Video Tools}

Lecturers can fuse general media materials in teaching sessions. Utilize some information illustrations or psyche planning and mind planning apparatuses that will help students' creative mind flourish and develop. These strategies won't just build up their capacity to tune in yet will likewise assist them with understanding the ideas better. For instance, lecturer can get configuration project introduction materials, direct live online conversations or playback accounts of public instructors. There is a great deal of brilliant applications for amazing slideshow or introductions.

\section{Classes Outside the Classroom}

Some lessons are best realized, when students are taught outside of the classroom. Sort out field trips that are applicable to the lessons or essentially go for exploration outside of the classroom. Design students will track down this new and energizing; they will learn and recall the things instructed quicker. Lecturer just need to arrange depending on the age group, utilize this technique for certain exercises; ensure keep it sufficiently straightforward to catch their mind and attention.

\section{Role Play}

Instructing through role play is an adequate method to make design students venture out of their customary range of familiarity and build up their relational abilities. This strategy proves to be useful, particularly when showing design case study or current design trends. The pretending approach will assist the design students with seeing how the teaching material 


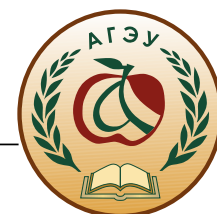

will be applicable to their daily tasks. This is a procedure that permits students to investigate practical circumstances by cooperating with others in a managed way to create insight and preliminary various techniques in a supported environment [15].

Conclusion. Whether lecturers are facing a lecture hall filled with 100 students or a small class with 10 students, one of the primary goals for the class should be actively engage students with innovative methods. Industrial Design students learn more when they participate in the design process of active learning through teaching innovation, whether it is through discussion, practice, review, or application.

The topics discussed above focus mainly on the literature definition and an overview of Industrial Design teaching innovation, including strategies and ideas. It is important to have a full understanding of each topic and the relation between them. The objectives of research were achieved based on these findings. It is hoped that this research can help Industrial Design lecturers conduct the Industrial Design courses and improve the student learning effectiveness in higher education.

Acknowledgement. I am thankful to my family who encouraged me and prayed for me throughout the time of my research. I thank all who in one way or another contributed to the completion of this research.

\section{References}

1 Arlinwibowo, J., Retnawati, H., \& Kartowagiran, B. (2021). How to Integrate STEM Education in Indonesian Curriculum? A Systematic Review. Challenges of Science. Issue IV, 2021, pp. 18-25. https://doi.org/10.31643/2021.03

2 Pratama H, Azman MNA, Zakaria NA, Khairudin M. The effectiveness of the kit portable PLC on electrical motors course among vocational school students in Aceh, Indonesia. Kompleksnoe Ispol'zovanie Mineral'nogo Syr'a = Complex Use of Mineral Resources. 2022;320(1): 75-87. https://doi.org/10.31643/2022/6445.09

3 Dominteanu, T. (2014). Modernisation And Employability The Center Of A New Strategy Higher Education Reform. Marathon, 6(1), 18-22.

4 McAleese, M. (2014). Realising the potential of quality in learning and teaching in higher education in Europe. FORMAZIONE \& INSEGNAMENTO. Rivista internazionale di Scienze dell'educazione e della formazione, 12(1), 19-24.

5 Hampson, J., Gunning, H., Nicholson, L., Gee, C., Jay, D., \& Sheppard, G. (2017). Role of clinical practice educators in an integrated community and mental health NHS foundation trust. Nursing Standard, 32(7), 49-55.

6 Markham, T. (2015). Redefining Smart: Awakening Students' Power to Reimagine Their World. Corwin Press.

7 Berkeley, U. C. (2017). Active Learning Strategies. Retrieved 31 October 2019, from http://www.teaching.berkeley.edu.

8 OECD., K. (2018). OECD Science, Technology and Innovation Outlook 2018. Paris: OECD Publishing.

9 Reeves, D. B. (2004). Accountability for learning: How teachers and school leaders can take charge. ASCD.

10 Carrol, N. E., \& Burke, M. (2010). Learning Effectiveness Using Different Teaching Modalities. American Journal of Business Education, 3(12), 65-76.

11 Nilson, L. B. (2016). Teaching at its best: A research-based resource for college instructors. John Wiley \& Sons.

12 Stuart, K. K. (2012). Reclaiming our agency: values based work for children, young people and families in an era of managerialism. 


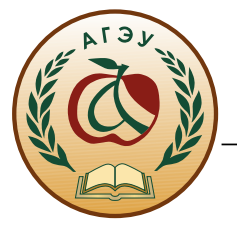

13 Berkeley, U. C. (2021). Active Learning Strategies. Retrieved 10 February 2021, from http://www.teaching.berkeley.edu.

14 Dove, J., \& Revilla, A. (2021). The best apps for teachers and educators. Retrieved 10 February 2021, from http://www.digitaltrends.com/mobile/best-apps-for-teacherseducation/

15 Glover, I. (2014). Role-play: An Approach to Teaching and Learning. Retrieved 12 February 2021, from http://blogs.shu.ac.uk/shutel/2014/07/04/role-play-an-approach-toteaching-and learning/?doing_wp_cron=1616997606.2809491157531738281250

16 Edsys. (2017). 16 Innovative Ideas to Make Your Teaching Methods More Effective. Retrieved 1 February 2021, from https://www.edsys.in/16-innovative-ideas-maketeaching-methods-effective/

17 Mohd Sharif, S., Basiran, M. F., \& Amon, N. (2021). Innovation in Teaching Methodology: Level of Student Acceptance of 'Boyles Law Apparatus' Teaching Aids in Thermodynamics Course. ANP Journal of Social Science and Humanities, 2(1), 46-54. https://doi.org/10.53797/anpjssh.v2i1.6.2021

\section{ӨНДІРІСТІК СТУДЕНТТЕРДІ ОКУ ТИІМДІЛІГІНЕ ОҚУ ИННОВАЦИЯЛАРЫНЫН ӘСЕРІ ЖОҒАРЫ ОҚУ ОҚУЫНДАҒЫ ДИЗАЙН Тео Пей Киан}

Оңзтүстік университет колледжі, Малайзия e-mail:pkteo@sc.edu.my

Аннотация: Бұл маққалада өнеркәсіптік дизайндавы білім берудегі инновацияны оқыттудың әсері талқыланады, қ̧овамдық сана сынынан өту үшін бәрін қайта ойлап табу қажет. Инновациялық білім вылыми жетістіктерді, технологиялық жетістіктерді, жаңуа саяси және экономикалық құрылымдарды, экологияльққ

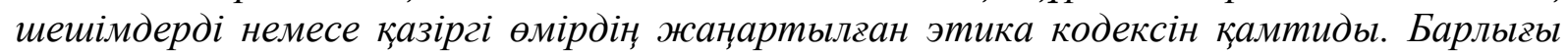
жаңашыл, қордан тыс ойлауды талап етеді, оқыыту мен оқу үшін қажет. Өнеркасіптік дизайн бойынша білім берудің бүгінгі күні студенттердің назарын аудару және идеяларды олар сыныптан шыққаннан кейін ұзақ уақыыт бойы сақтайтын етіп жеткізу больип табылады. Бұл өнеркәсіптік дизайн мұвалімдеріне инноващияның дамуына әсер ететін нұсқаулық инновациялар жиынтызы құжжет екенін білдіреді. Сондықтан оқытудың тиімділігін оқытудавы жынаңашылдық ретінде қарастырылатын элементтерді, идеяларды және әдістерді меңзеру үшін мазмұн зерттеледі. Бұл мақ̧аланың мақссаты өнеркәсіптік дизайн бавдарламасында инновачияльқ оқыту әдістерінің әсерін анықтау және инновачиялық оқыту проиестерінің өнеркәсіптік дизайн бавдарламасында оқылтудың тиімділігіне құалай әсер ететінін зерттеу болып табылады. Бұл маққала аккредиттелген валымдар мен зерттеушілерден тақырыл бойынша қзосымша деректерді жинайды; тақырып бойынша бар зерттеулерді сыни тұрвыдан құарастырады; және құарама-ққарсы көзқарастар мен теориялық көзқұарастарды талдайды. Осылайша, бұл мақалада өнеркәсіптік дизайндавы инновачияларды оқыту тұжырымдамасы және жовары оқу орындарында өнеркәсіптік дизайн студенттерін оқытудың тиімділігі жинақталван.

Түйін сөздер: өнеркәсіптік дизайн бойынша білім, оқыту инновациялары, жовары білім, оқытудың тиімділігі. 


\title{
ВЛИЯНИЕ ОБУЧАЮЩИХ ИННОВАЦИЙ НА ЭФФЕКТИВНОСТЬ ОБУЧЕНИЯ СТУДЕНТОВ ПРОМЫШЛЕННЫХ ДИЗАЙН В ВЫСШЕМ ОБРАЗОВАНИИ
}

\author{
Тео Пей Киан \\ Южный университетский колледж, Малайзия \\ e-mail:pkteo@sc.edu.my
}

\begin{abstract}
Аннотация: В этой статье обсуждается эффект обучения инновачиям в образовании по промышленному дизайну, необходимо заново изобрести все, чтобы преодолеть вызов общественного сознания. Обучение инновациям включает в себя научные достижения, технологические прорывы, новые политические и экономические структуры, экологические решения или обновленный кодекс этики для современной жизни. Все требует инновачионного, нестандартного мышления, необходимого в преподавании и обучении. Задача сегодня для образования в области промышленного дизайна состоит в том, как привлечь внимание студентов и донести идеи таким образом, чтобь они оставались с ними еще долго после того, как они покинут класс. Это означает, что преподавателям промышленного дизайна нужен набор учебных инноваций, влияющих на инновачионное развитие. Таким образом, содержание исследует, чтобы усвоить элементы, идеи и методы, которые рассматриваются как инновации в обучении эффективности обучения. Цели этой статьи - определить влияние методов обучения инновачиям в программе промышленного дизайна и изучить, как процессь обучения инновачиям влияют на эффективность обучения в программе промышленного дизайна. В этой статье собраны вторичные данные по теме от аккредитованных ученых и исследователей; критически рассматривает существующие исследования по теме; и анализирует противоположные точки зрения и теоретические подходы. Таким образом, в этой статье консолидируется концепщия обучения инновациям в области промышленного дизайна и эффективности обучения студентов, изучаюших промыиленный дизайн, в высших учебных заведениях.
\end{abstract}

Ключевые слова: образование в области промышленного дизайна, инноващии в обучении, высшее образование, эффективность обучения.

Author information

Teo Pei Kian - PhD. in Education (Technical and Engineering), Dean of Faculty of Art and Design, Southern University College, Malaysia, Email: pkteo@sc.edu.my

Автор туралы ақпарат

Тео Пей Киан - PhD. білім беру (техникальқж және инженерия), өнер және дизайн факультетінің деканы, Оңтүстік университет колледжі, Малайзия, Электрондық пошта: pkteo@sc.edu.my

Информация об авторе

Тео Пей Киан - доктор философии. Кандидат педагогических наук (технический и инженернылй), декан факультета искусства и дизайна Южного университетского колледжа, Малайзия, электронная nочma: pkteo@sc.edu.my 


\section{ПРАВИЛА ДЛЯ АВТОРОВ ЖУРНАЛА}

(с учетом изменений в Требованиях к научным изданиям для включения их в Перечень изданий, рекомендуемых для публикации результатов научной деятельности-Приказ Министра образования и науки Республики Казахстан от 30 апреля 2020 года № 170)

Журнал «Статистика, учет и аудит» (в дальнейшем - Журнал) публикует оригинальные работы ученых и специалистов научно-исследовательских организаций, высших учебных заведений, организаций и административных структур Казахстана, а также иностранных авторов. В журнале публикуются оригинальные статьи по научным направлениям статистики, учета и аудита, микро и макроэкономические вопросы международной и отечественной экономики, финансов, информатики и педагогики. Также публикуются рецензии, хроники научной жизни и др. материалы, имеющие отношение к деятельности Учредителя журнала.

Обязательными условиями для публикации являются:

1.Соответствие публикуемых научных статей (в том числе обзоров) заявленной цели и тематическому направлению журнала. Научная статья - изложение собственных выводов и промежуточных или окончательных результатов научного исследования, экспериментальной или аналитической деятельности, содержащее авторские разработки, выводы, рекомендаций ранее не опубликованные и обладающие новизной; или посвященное рассмотрению ранее опубликованных научных статей, связанных общей темой (систематический обзор).

2.Структура научной статьи включает название, аннотацию, ключевые слова, основные положения, введение, материаль и методы, результаты, обсуждение, заключение, информацию о финансировании (при наличии), список литературы. В каждой оригинальной статье (за исключением социально-гуманитарного направления) обеспечивается воспроизводимость результатов исследования, описывается методология исследования с указанием происхождения оборудования и материалов, методов статистической обработки данных и других способов обеспечения воспроизводимости. Содержание других типов публикаций не превышает 10\% (десять) от общего количества статей в номере. При этом автор или коллектив авторов вносят значительный вклад в концепцию, научный дизайн, исполнение или интерпретацию заявленного научного исследования и создание научной статьи. Наличие библиографической информации - заголовка статьи, аннотации, ключевых слов, информации об авторах на английском языке обязательно.

2.1 В аннотации (аңдатпа, abstract) публикуемой статьи на языке статьи излагаются суть и использованные методы исследования, суммируются наиболее важные результаты и их значимость. Объем аннотации составляет не более 300 слов (минимальный объем-100 слов). 


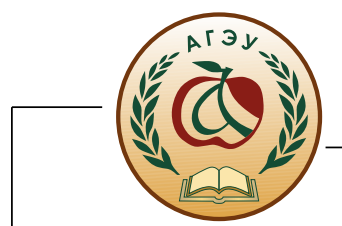

2.2 Резюме (түйін, summary) на двух не на языке статьи (казахском, русском и английском) языках. Например, резюме и summary- это не переводы аңдатпа, а краткое изложение о статье на русском и английском языках (если статья написана на казахском) и рекомендуется их приводить после списка литературы.

2.3 Ключевые слова (түйінді сөздер, key words) предназначены для поиска текста статьи и определения ее предметной области. Например, они приводятся после аннотации (если статья написана на русском) и двух резюме (түйін, summary). Ключевые слова должны обеспечить наиболее полное раскрытие содержания статьи.

2.4 Информация об авторах - имена (Фамилия И.О. авторов), аффилиации (полное название учреждения, которое представляет автор (авторы), название страны, и адреса всех авторов публикаций, в том числе с указанием основного автора-выделить звездочкой (*), е-таil (основного автора).

3. Список литературы. Ссылки на источники в тексте статьи даются только в квадратных скобках (без цитирования [12], при цитировании или пересказе авторского текста [12, с. 29]). Используемая литература, указываемая в ссылках, дается в конце статьи пронумерованной и в порядке упоминания по авторам. Архивные материалы в список не включаются, ссылки на них помещаются в тексте в круглых скобках. При использовании в статье: источников законодательных, нормативно-правовых актовссылки на них делать в тексте сразу же после них, а источников из электронных ресурсов или удаленного доступа (Интернета) в списке литературы приводится библиографическая запись источника и ссылка на сетевой ресурс с полным сетевым адресом в Интернете. Желательно указывать дату обращения к ресурсу. Список литературы предоставляется на языке оригинала и должен состоять не более чем из 20 наименований.

3.1 Наличие транслитерированных списков литературы (используемых источников) к каждой статье. Существуют различные системы транслитераций. Предложение редакции по транслитерации (вы имеете право найти другой способ):

3.1. На данной странице Вы можете выполнить транслит - онлайн русских букв латиницей:

Транслитерация с русского на английский онлайн

https://lim-english.com/posts/transliteratsiya-s-russkogo-na-angliiskij/

4. Ответственность за содержание статей несут авторы.

5. Этические принципы, которыми должен руководствоваться автор научной публикации. Представление статьи на рассмотрение в редакцию подразумевает, что она содержит полученные автором (коллективом авторов) новые научные результаты, которые ранее нигде не публиковались. Автор должен осознавать, что несет персональную ответственность за представляемый текст рукописи. Это предполагает соблюдение следующих принципов:

5.1. Автор статьи гарантирует, что предоставляет редакции журнала достоверные результаты выполненной научной работы или исследования. Заведомо ложные или 
сфальсифицированные утверждения приравниваются к неэтичному поведению и являются неприемлемыми.

5.2. В случае, если главный редактор журнала запрашивает у автора научной статьи ее исходные данные для рецензирования, автор, если это возможно, должен быть готов предоставить открытый доступ к таким данным; автор также берет на себя обязательство сохранять исходные материалы статьи в течение разумного периода, прошедшего после ее публикации.

5.3. Автор гарантирует, что результаты исследования, изложенные в рукописи, представляют собой самостоятельную и оригинальную работу. В случае использования фрагментов чужих работ или заимствования утверждений других авторов, в статье должны быть оформлены соответствующие библиографические ссылки с обязательным указанием автора и первоисточника. Все статьи проходят обязательную проверку через систему «Антиплагиат». Все статьи проверяются на предмет обнаружения плагиата (оригинальность должна быть не менее 70\%). Применяется лицензионная программа АНТИПЛАГИАТ.ВУЗ Договор № 1065 от 29 декабря 2020 г.) Чрезмерные заимствования, а также плагиат в любых формах, включая неоформленные цитаты, перефразирование или присвоение прав на результаты чужих исследований, являются неэтичными и неприемлемыми действиями. Статьи, представляющие собой компиляции из материалов, ранее опубликованных другими авторами, без их творческой переработки и собственного авторского осмысления, редакцией журнала к публикации не принимаются.

5.4. Автор безусловно признает вклад всех лиц, так или иначе повлиявших на ход исследования или определивших характер представленной научной работы. В частности, в статье должны быть сделаны библиографические ссылки на отечественные и зарубежные публикации, которые имели значение при проведении исследования. Информация, полученная в частном порядке путем разговора, переписки или обсуждения с третьими лицами, не должна использоваться без получения открытого письменного разрешения от ее источника. Все источники должны быть раскрыты. Даже в том случае, если используемые в статье письменные или иллюстративные материалы получены от большого числа людей, автору статьи необходимо представить в редакцию все соответствующие разрешения на использование этих материалов.

5.5. Автор гарантирует, что представленная в журнал рукопись статьи не находится на рассмотрении редакции другого научного журнала и не была ранее опубликована в другом журнале. Несоблюдение этого принципа расценивается как грубое нарушение этики публикаций и дает основание для снятия статьи с рецензирования. Текст статьи должен быть оригинальным, то есть публиковаться в представленном виде в периодическом печатном издании впервые. Если элементы рукописи ранее были опубликованы в другой статье, автор обязан сослаться на более раннюю работу и указать, в чем состоит существенное отличие новой работы от предыдущей. Дословное копирование собственных работ и их перефразирование неприемлемы, они могут быть использованы только как основа для новых выводов. 


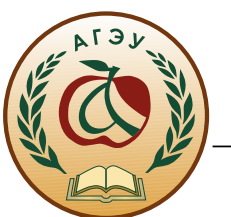

5.6. Автор статьи гарантирует правильность списка соавторов. В числе соавторов должны быть указаны все лица, внесшие существенный интеллектуальный вклад в концепцию, структуру, а также в проведение или интерпретацию результатов представленной работы. Другим лицам, чье участие в представленной в журнал работе ограничилось некоторыми ее аспектами, должна быть выражена благодарность. Автор статьи должен также гарантировать, что все соавторы ознакомлены с окончательным вариантом статьи, одобрили его и согласны с ее представлением к публикации. Все указанные в статье соавторы несут совокупную ответственность за ее содержание. Если статья является мультидисциплинарной работой, соавторы могут также принимать на себя ответственность за свой личный вклад в работу, продолжая при этом нести коллективную ответственность за результат исследования в целом. Недопустимо указание в качестве соавторов статьи лиц, не принимавших участия в исследовании.

5.7. В случае обнаружения существенных ошибок или неточностей в статье на этапе ее рассмотрения или после ее опубликования автор обязан незамедлительно уведомить об этом редакцию журнала и принять совместное решение о признании ошибки и/или ее исправлении в максимально короткие сроки. Если редакция узнает от третьего лица, что опубликованная работа содержит существенные ошибки, автор обязан незамедлительно исправить их либо предоставить редакции доказательства правильности ранее предоставленной им информации.

5.8. Автор обязуется указывать в своих рукописях все источники финансирования работы, заявлять о возможных конфликтах интересов, которые могут повлиять на результаты исследования, их интерпретацию, а также на суждения рецензентов. Потенциальные конфликты интересов должны быть раскрыты как можно раньше.

6. Поступившие от авторов научные статьи проходят первичный контроль на комплектность и правильность оформления. Далее статья направляется на предмет обнаружения плагиата (оригинальность должна быть не менее 70\%). Применяется лицензионная программа АНТИПЛАГИАТ.ВУЗ Договор № 1065 от 29 декабря 2020 г.), после чего, научные статьи, поступившие в редакцию, проходят обязательное слепое рецензирование порядок прохождения, которых описан в разделе Рецензирование.

При отрицательном отзыве рецензентов редакция Журнала обязуется сообщать авторам все комментарии об их работе, сделанные рецензентами, если только они не содержат обидные или клеветнические замечания.

7. В конце статьи предоставляются заполненные формы для размещения сборника статей в Научной электронной библиотеке (eLibrary.ru) и включения сборника статей в Российский индекс научного цитирования (РИНЦ):

\section{ФОРМА}

для размещения сборника статей в Научной электронной библиотеке (eLibrary.ru) и включения сборника статей в Российский индекс научного цитирования (РИНЦ)

1. Название статьи: на казахском, русском и английском языках 
2. Сведения об авторе (авторах):

- фамилия, имя, отчество (полностью) автора (авторов) с указанием ученой степени и ученого звания (при наличии) на трех языках:

- место работы автора (авторов) (должность и организация) на трех языках:

- контактная информация:

e-mail автора (авторов) - тел.номер автора (авторов) -

8. Редакция оставляет за собой право редакторской правки.

Технические требования

1. Общий объем статьи, включая аннотацию, ключевые слова, литературу, таблицы и рисунки не должен превышать 6-8 страниц. Исключение составляют заказные и обзорные статьи.

2. Статьи должны быть оформлены в строгом соответствии шрифтом гарнитуры Times New Roman.

МРНТИ

\section{Схематический пример оформления статьи}

УДК 339.74

DOI (Digital Object Identifier) xxxxxxxxxx

По центру приводятся: Название статьи

(Поля: сверху - 2 см., слева-3 см., справа -1,5 см. Шрифт полужирный. Кегль-14 пт, межстрочный интервал - одинарный.)

Фамилии и инициалы авторов (напр.И.В.Иванов, Ю.П.Крылов)

Полное название учреждения, которое представляе(ю)т автор(ы) с указанием города и страны, электронного адреса основного автора выделением надстрочной звездочкой. Если авторы из разных учреждений, то соответствие между автором и учреждением устанавливается надстрочными индексами, например:

\section{${ }^{*}$ И.В. Иванов ${ }^{1}$, Ю.П. Крылов ${ }^{2}$}

${ }^{1}$ Алматинский гуманитарно-экономический университет, Алматы, Казахстан 2 Международная академия бизнеса, Алматы, Казахстан e-mail: ivanov@mail.ru

- Аннотация.

- Ключевые слова.

- Текст статьи: Поля: сверху, снизу - 2 см., слева - 3 см., справа -1,5 см. Шрифт Times New Roman. Кегль-14 пт. Абзацный отступ-1,25 см., межстрочный интервал одинарный).

- Список литературы. Транслитерированный список литературы (References)

- После списка литературы приводятся:

Название статьи перед каждым резюме на двух не на языке статьи (казахском, русском и английском) языках. 
ISSN 1563-2415

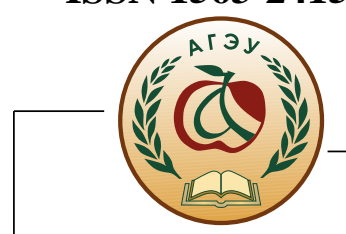

После каждого названия статьи приводятся см. выше (последовательно) пп. 2.4, 2.2, 2.3 Руководства для авторов

3. Таблицы и рисунки с названиями должны быть пронумерованы по порядку (если их несколько). Нумерация таблицы (Таблица 1.) должна быть расположена вверху слева выше названия таблицы через абзацный отступ.

4. Рисунки, фотографии, таблицы должны быть четкими и контрастнымив формате jpg, иметь разрешение не менее 300 dpi, подрисуночные надписи к ним должны быть расположены ниже рисунка по центру. Цветные рисунки, диаграммы не допускаются.

5. На рисунках должен быть минимум буквенных и цифровых обозначений, обязательно объясненных в статье или подрисуночных подписях.

6. Необъясненные сокращения слов, имен, названий, кроме общепринятых, не допускаются. Аббревиатуры расшифровываются после первого появления в тексте, например: Организация по экономическому сотрудничеству и развитию (ОЭСР).

7. Упомянутые в статьях единицы измерения должны соответствовать Международной системе единиц СИ.

8. Математические формулы должны быть набраны в Microsoft Education (каждая формула - один объект). Нумеровать следует лишь те формулы, на которые имеются ссылки.

9. Редакция не занимается литературной и стилистической обработкой статей. Материалы, статьи не возвращаются

10. Авторам для рассмотрения статьи необходимо представить рукопись на сайт www.sua.aesa.kz, и копию статьи со всеми сопроводительными документами согласно требованию направить на e-mail: zhurnal.aesa.99@ mail.ru :

10.1. Электронную версию статьи;

10.2.Наукометрическую базу данных для РИНЦ

10.3. Представить сканированную копию квитанцию об оплате за публикацию статьи и квитанцию об оплате за присвоение DOI (Digital Object Identifier) авторам, (только после подтверждения редакцией Журнала статьи к опубликованию).

ВНИМАНИЕ: DОI (Digital Object Identifier) присваивается регистрационным агентством International DOI Foundation (Интернэйщенел ДОИ Фаундэйщен). 